\title{
Managing risks of precast concrete supply chain: a case study
}

\author{
Jati Utomo Dwi Hatmoko ${ }^{1, *}$, Mochamad Agung Wibowo ${ }^{1}$, Marita Dewi Astuty ${ }^{2}$, Desy Ratna Arthaningtyas ${ }^{1}$, Moh Nur \\ Sholeh ${ }^{3}$ \\ ${ }^{1}$ Department of Civil Engineering, Faculty of Engineering, Diponegoro University, Semarang, Indonesia \\ ${ }^{2}$ Directorat of Infrastructure Investment Development, Directorate General of Construction Development, Ministry of Public Works \\ and Housing, Jakarta, Indonesia \\ ${ }^{3}$ Civil Engineering Study Program, Vocational School, Diponegoro University, Semarang, Indonesia
}

\begin{abstract}
Precast concrete has typically long lead time, starting from order placement, production stage, to delivery to project site, all of which requires good supply chain management. As a consequence, the risks of its supply chains are inevitable and must be anticipated to ensure the success of a project. The aim of this research is to assess the risks of the supply chain of precast concrete from production to delivery to projects. WKB, a government-owned company that produces precast concrete, has been used as the case study. Activities along the supply chain were mapped based on five dimensions of Supply Chain Operation Reference (SCOR), i.e. Plan - Source - Make - Deliver - Return, upon which risks were identified. Data was collected through in-depth interview and questionnaire survey to key persons of WKB. A 1-5 Likert scale was used to quantify the occurrence and severity of risks along the supply chain. The identified risks were classified into four levels based on the multiplication of the occurrence and the severity, i.e. critical, major, moderate, and minor. A total of nine critical risks were found along the supply chain, i.e. sales forecast and planning for production (Plan); production capacity of natural material vendors (Source); sudden change of production, shortage of skilled workers, additional cost for land stockyard rental, and renewal for industrial land lease license (Make); risk of non-standard transportation (Deliver); defective and failed products (Return). This research provides a valuable understanding of the risks of the precast concrete supply chain and the mitigation strategies.
\end{abstract}

\section{Introduction}

Supply chain management has increasingly been seen as one of the significant factors of a project success. It has been developed in more sustainable approaches and utilizing inter-organizational resources [1]. In addition, increased collaboration and performance in the construction supply chain is also seen paramount $[2,3]$, particularly in the context of lean construction concept.

Nowadays, precast concrete is widely used in many construction projects [4]. Previous research revealed that a proper supply chain management of precast concrete could save project costs of $17.7 \%, 35.7 \%$, and $15.4 \%$, respectively [5]. In addition, the implementation of Just in Time (JIT) model can reduce up to $10.7 \%$ of usual project time [6]. The precast concrete supply chain is also affected by the hybrid life cycle, because it extends the boundaries of the process method, and reduces the inputoutput (I-O) life cycle assessment sensitivity of fluctuations in raw material prices for product manufacturing [7].

One of common problems of the precast concrete is frequent delays. It is known that it has typically long lead time, starting from order placement, production stage, to delivery to project site [5]. As a consequence, these risks of the supply chains are inevitable, and must be anticipated and managed through comprehensive supply chain risk management to ensure the success of the project.

Construction risk management is defined as the process of identifying, analysing, and responding to any risks that arise during the construction project's lifecycle to help the project stay on track and fulfil its objectives [8]. Some of the impacts of project risk management is the increasing capacity of that support the success of the project by $10.7 \%$ [9], capital investment and project efficiency [10], and organizational change needs [11]. Previous research has also examined decision parameters in precast concrete supply chains with quantitative analytic modelling [12]. An integrated management of onsite, coordination, and off-site uncertainty within hybrid project arrangements have been carried out resulting practical use for project managers by facilitating risk identification and analysis in various dimensions of highrisk projects [13]. In addition, a research has been carried out regarding risk management on prefabricated housing in Hong Kong with a social network analysis approach [14].

\footnotetext{
${ }^{*}$ Corresponding author: jati.hatmoko@,ft.undip.ac.id
} 
One of current supply chain performance measurement models is known as Supply Chain Operations References (SCOR). SCOR is a process reference model developed by the Supply Chain Council that describes the company's business activities for customers [15]. SCOR has been applied in measuring the performance of the construction supply chain in a case study, but has not measured the risks in detailed. [16].

The aim of this research is to assess the risks of the supply chain of precast concrete from production to delivery to projects. WKB, a government-owned company that produces precast concrete, has been used as the case study. Activities along the supply chain were mapped based on the five dimensions of SCOR, i.e. Plan - Source - Make - Deliver - Return, upon which risks were identified.

\section{Literature Review}

\subsection{Construction supply chain management}

The construction industry is one of the least integrated among all major industries. One of the efforts to improve the integration with sustainable supply chain management. There are five requirements to support supply chain integration: (1) low costs, (2) ease of installation and configuration, (3) access can be adjusted to information and applications, (4) ability to integrate external systems and information, and (5) ease of connection and integration [17].

Previous research describes supply chain management simulations on medium-size building projects that show the project's median delay is 67 days $(22 \%$ of the project duration) [18]. Research on integrated models for the selection of green partners and supply chain construction combines Analytic Network Process (ANP) and MultiObjective Programming (MOP) with the results of supplier selection depending on environmental factors, business, and eco-efficiency ratio [19]. Supply chain construction performance has been measured by Supply Chain Operations References (SCOR) combined with the Analytical Hierarchy Process (AHP) and Matrix Objectives (Omax) [16]. Long before, the impact of construction supply chain management was simulated on the presence or absence of subcontractors and changes in material delivery time [20].

\subsection{Supply chain of precast concrete}

Precast concrete production increases every year because of the need for fast and efficient development [21]. The precast concrete supply chain is related to two sides. The first side is to supply raw materials, such as cement, sand, and steel, while the second side is to contractors who work on projects on site [22]. Engineering Procurement Construction (EPC) has been analysed in a study through the current state mapping of the supply chain material including precast concrete that describes the specific time in each phase of procurement [23]. This precast concrete supply chain is seen increasingly more attractive because of its large-scale material, off-site manufacturing process, and reduce energy consumption by $16-24 \%$ when compared to on-site casting [24].

\subsection{Supply chain risks}

The general theory of risk management is risk identification, risk assessment, risk response, implementation, evaluate and review. Supply chain risk has been investigated by many researchers by contributing in the area of defining, operating and mitigating risks [25]. Supply chain risk management is needed in managing uncertainty in price, quality, material delivery time [26]. Previous research on the risk of construction supply chain management is risk factor classification and analysis based on responsibility and decision level, the contractor is the main person in charge of identifying and controlling risk factors and their placement, especially at the level of planning decisions [27].

\subsection{Supply Chain Operation Reference (SCOR) model}

The Supply Chain Operations Reference (SCOR) is a model that supports the development of the Performance Measurement System (PMS). SCOR function is not only to measure and improve the internal and external business processes of the company [28], but also displays a crossfunctional framework that links business processes measurement of techniques, guidelines, and performance [29]. The SCOR model, perfect order fulfilment and overall value at risk, have been used to measure supply chains for material construction to support sustainable construction [30], as well as to measure supply chain performance in building projects [31].

\section{Research method}

Data was collected through in-depth interview and questionnaire survey to key persons of WKB. The key persons are the top management of WKB with more than 10 years' experience in their positions, demonstrating a comprehensive knowledge of the operational and business processes in the company.

A 1-5 Likert scale was used to quantify the occurrence and severity of risks along the supply chain. The 1-5 Likert scale was used to represent the level of risk occurrence, i.e. rare, unlikely, possible, likely, and almost certain. The same 1-5 scale was also used to represent the level of risk severity, i.e. insignificant, minor, moderate, major, and critical. The identified risks were later classified into four risk levels based on the multiplication of the occurrence and the severity, i.e. minor, moderate, major and critical.

\section{Case study: managing risks supply chain in the precast concrete industry}

WKB is a state-owned enterprise engaged in precast concrete business, whereas its main activities are 
producing PC poles, PC piles, railways concrete product, bridge concrete product, sheet piles, $\mathrm{PC}$ pipes, $\mathrm{RC}$ box culvert, marine concrete product, hollow core slab, PC cylinder pile, $\mathrm{PC}$ wall, hydro $\mathrm{CP}$. It is located in Boyolali - Semarang Km. 4,5 Mojosongo, Boyolali, Central Java, Indonesia.

\subsection{Mapping of the company's supply chain activities}

Table 1 shows the identification and classification of supply chain activities of WKB based on the dimensions of the SCOR. The use of SCOR was intended to see the potential risks to the planning carried out to run the business well (plan), the resources used (source), the transformation process carried out to manage raw materials into products (make), delivery of consumer products (deliver), and returns that occur from consumers and suppliers (return).

Table 1. Mapping of supply chain activities based on SCOR

\begin{tabular}{|c|c|c|}
\hline 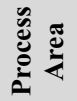 & $\begin{array}{l}\text { Sub Process/ } \\
\text { Activity }\end{array}$ & Detailed Activities \\
\hline \multirow{6}{*}{$\frac{\tilde{z}}{2}$} & \multirow{2}{*}{$\begin{array}{l}\text { Demand for } \\
\text { concrete } \\
\text { products }\end{array}$} & $\begin{array}{l}\text { Receive item release warrant issued } \\
\text { by the sales area }\end{array}$ \\
\hline & & Calculate and check order quantities \\
\hline & \multirow[t]{4}{*}{$\begin{array}{l}\text { Production } \\
\text { planning }\end{array}$} & $\begin{array}{l}\text { Calculate materials/ tools/ mould/ } \\
\text { production line planning requirements }\end{array}$ \\
\hline & & $\begin{array}{l}\text { Calculate human resources } \\
\text { requirements }\end{array}$ \\
\hline & & $\begin{array}{l}\text { Calculate and submit plans for the } \\
\text { needs of fields funds/work units }\end{array}$ \\
\hline & & $\begin{array}{l}\text { Check stocks in factories that have } \\
\text { concrete plants (free stock) }\end{array}$ \\
\hline \multirow{6}{*}{$\begin{array}{c}\stackrel{\Xi}{\Xi} \\
\vdots \\
\vdots\end{array}$} & \multirow{4}{*}{$\begin{array}{l}\text { Procurement of } \\
\text { materials }\end{array}$} & Price negotiation \\
\hline & & Supplier selection \\
\hline & & Receive of raw material delivery \\
\hline & & Evaluation of supplier assessment \\
\hline & \multirow{2}{*}{$\begin{array}{l}\text { Raw material } \\
\text { testing, } \\
\text { acceptance, and } \\
\text { inspection }\end{array}$} & Suitability of material specifications \\
\hline & & Material quality \\
\hline \multirow{8}{*}{ 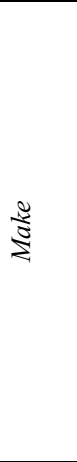 } & \multirow{5}{*}{$\begin{array}{l}\text { Process of } \\
\text { production }\end{array}$} & Production scheduling \\
\hline & & Production execution and control \\
\hline & & $\begin{array}{l}\text { Allocation and mobility of } \\
\text { tools/machines }\end{array}$ \\
\hline & & $\begin{array}{l}\text { Human resource needs } \\
\text { (foreman/vendor) }\end{array}$ \\
\hline & & $\begin{array}{l}\text { Mutation of a stock position, product } \\
\text { rolling, and production evaluation }\end{array}$ \\
\hline & \multirow[t]{3}{*}{$\begin{array}{l}\text { Handling the } \\
\text { finished product }\end{array}$} & $\begin{array}{l}\text { Classify finished products (checking } \\
\text { concrete products) }\end{array}$ \\
\hline & & $\begin{array}{l}\text { Prepare land for the storage of } \\
\text { finished products }\end{array}$ \\
\hline & & $\begin{array}{l}\text { Concrete stacking and maintenance } \\
\text { procedures during storage }\end{array}$ \\
\hline \multirow{4}{*}{$\frac{\dot{a}}{a}$} & \multirow{3}{*}{$\begin{array}{l}\text { Delivery and } \\
\text { after sales } \\
\text { service }\end{array}$} & Selection of means of transportation \\
\hline & & Information on field conditions \\
\hline & & Delivery schedule information \\
\hline & Bill handling & $\begin{array}{l}\text { Submit monthly payment reports to } \\
\text { customers }\end{array}$ \\
\hline \multirow{2}{*}{ 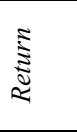 } & \multirow{2}{*}{$\begin{array}{l}\text { Product return } \\
\text { for non- } \\
\text { conformity }\end{array}$} & $\begin{array}{l}\text { Handling of materials that are } \\
\text { rejected/delayed from suppliers }\end{array}$ \\
\hline & & $\begin{array}{l}\text { Handling of failed/defective products } \\
\text { at the time of production/ installation }\end{array}$ \\
\hline
\end{tabular}

\subsection{Risk analysis and risk priority}

As shown in Table 2, risks are identified for each of the supply chain activities. These risks are later analysed quantitatively by identifying the levels of occurrence and severity, resulting in four risk levels, i.e. minor, moderate, major, and critical. These risks were ranked based on their value of priority index (RPI) from the highest to the lowest.

Table 2. Risk Analysis

\begin{tabular}{|c|c|c|c|c|c|c|}
\hline Code & Risk Identified & LO & LS & RPI & LR & $\mathbf{R P}$ \\
\hline (1) & (2) & (3) & (4) & $\begin{array}{c}(5)= \\
(3) *(4)\end{array}$ & (6) & (7) \\
\hline $\mathrm{A} 1$ & $\begin{array}{l}\text { Sales forecast } \\
\text { not accurate }\end{array}$ & 4 & 5 & 20 & $C$ & 1 \\
\hline $\mathrm{A} 2$ & $\begin{array}{l}\text { Order changes } \\
\text { or request }\end{array}$ & 3 & 3 & 9 & $M J$ & 16 \\
\hline A3 & $\begin{array}{l}\text { Weak planning } \\
\text { and preparation } \\
\text { carried out prior } \\
\text { to production }\end{array}$ & 4 & 4 & 16 & $C$ & 6 \\
\hline A4 & $\begin{array}{l}\text { Unrealized } \\
\text { material } \\
\text { procurement }\end{array}$ & 3 & 3 & 9 & $M J$ & 17 \\
\hline A5 & $\begin{array}{l}\text { An inaccurate } \\
\text { stock of } \\
\text { materials in the } \\
\text { warehouse }\end{array}$ & 2 & 3 & 6 & $M$ & 31 \\
\hline A6 & $\begin{array}{l}\text { The number of } \\
\text { production } \\
\text { personnel is } \\
\text { limited }\end{array}$ & 3 & 3 & 9 & $M J$ & 18 \\
\hline A7 & $\begin{array}{l}\text { Production } \\
\text { costs affect the } \\
\text { cost of goods } \\
\text { sold due to a } \\
\text { high price of } \\
\text { industrial } \\
\text { materials from } \\
\text { the head office }\end{array}$ & 3 & 4 & 12 & $M J$ & 10 \\
\hline A8 & $\begin{array}{l}\text { Incompatibility } \\
\text { of product stock } \\
\text { available with } \\
\text { an order request }\end{array}$ & 3 & 3 & 9 & $M J$ & 19 \\
\hline A9 & $\begin{array}{l}\text { Price monopoly } \\
\text { due to the } \\
\text { scarcity of } \\
\text { natural } \\
\text { materials and } \\
\text { competition in } \\
\text { obtaining raw } \\
\text { materials }\end{array}$ & 2 & 3 & 6 & $M$ & 32 \\
\hline A10 & $\begin{array}{l}\text { The accuracy of } \\
\text { supplier } \\
\text { material } \\
\text { delivery } \\
\text { schedule } \\
\text { information }\end{array}$ & 3 & 3 & 9 & $M J$ & 20 \\
\hline A11 & $\begin{array}{l}\text { The supplier } \\
\text { does not fulfil } \\
\text { material } \\
\text { delivery } \\
\text { commitments }\end{array}$ & 3 & 3 & 9 & $M J$ & 21 \\
\hline A12 & $\begin{array}{l}\text { Disruption of } \\
\text { the supply of } \\
\text { natural material } \\
\text { raw materials }\end{array}$ & 4 & 3 & 12 & $M J$ & 11 \\
\hline A13 & $\begin{array}{l}\text { Supplier } \\
\text { performance } \\
\text { evaluation is not } \\
\text { updated }\end{array}$ & 3 & 3 & 9 & $M J$ & 22 \\
\hline
\end{tabular}




\begin{tabular}{|c|c|c|c|c|c|c|}
\hline Code & Risk Identified & LO & LS & RPI & LR & $\mathbf{R P}$ \\
\hline A14 & $\begin{array}{l}\text { The reduced } \\
\text { production } \\
\text { capacity of } \\
\text { several vendors, } \\
\text { especially in } \\
\text { split material }\end{array}$ & 4 & 5 & 20 & $C$ & 2 \\
\hline A15 & $\begin{array}{l}\text { The scarcity of } \\
\text { materials } \\
\text { related to } \\
\text { government } \\
\text { regulations on } \\
\text { environmental } \\
\text { policy }\end{array}$ & 3 & 3 & 9 & $M J$ & 23 \\
\hline A16 & $\begin{array}{l}\text { Material } \\
\text { acceptance is } \\
\text { not in } \\
\text { accordance with } \\
\text { the order }\end{array}$ & 4 & 3 & 12 & $M J$ & 12 \\
\hline A17 & $\begin{array}{l}\text { Changes in } \\
\text { sudden } \\
\text { production } \\
\text { plans }\end{array}$ & 4 & 5 & 20 & $C$ & 3 \\
\hline A18 & $\begin{array}{l}\text { The spinning } \\
\text { process is } \\
\text { hampered in } \\
\text { centrifugal } \\
\text { products }\end{array}$ & 3 & 3 & 9 & $M J$ & 24 \\
\hline A19 & $\begin{array}{l}\text { Occupational } \\
\text { health and } \\
\text { safety risk (K3) }\end{array}$ & 3 & 3 & 9 & $M J$ & 25 \\
\hline A20 & $\begin{array}{l}\text { Disruption of } \\
\text { operations due } \\
\text { to } \\
\text { environmental } \\
\text { disaster issue }\end{array}$ & 2 & 4 & 8 & $M J$ & 30 \\
\hline A21 & $\begin{array}{l}\text { Lack of } \\
\text { concrete } \\
\text { printing tools }\end{array}$ & 3 & 4 & 12 & $M J$ & 13 \\
\hline A22 & $\begin{array}{l}\text { Printing } \\
\text { machine } \\
\text { damage }\end{array}$ & 3 & 4 & 12 & $M J$ & 14 \\
\hline A23 & $\begin{array}{l}\text { Low employee } \\
\text { performance/ } \\
\text { productivity }\end{array}$ & 2 & 2 & 4 & $M$ & 36 \\
\hline A24 & $\begin{array}{l}\text { Less skilled } \\
\text { workforce }\end{array}$ & 4 & 4 & 16 & $C$ & 7 \\
\hline A25 & $\begin{array}{l}\text { Stock } \\
\text { mismatches } \\
\text { cause }\end{array}$ & 3 & 3 & 9 & $M J$ & 26 \\
\hline A26 & $\begin{array}{l}\text { Quality of } \\
\text { production is } \\
\text { not according to } \\
\text { standards }\end{array}$ & 3 & 3 & 9 & $M J$ & 27 \\
\hline A27 & $\begin{array}{l}\text { The period of } \\
\text { land lease } \\
\text { permits expired }\end{array}$ & 3 & 5 & 15 & $C$ & 9 \\
\hline A28 & $\begin{array}{l}\text { Increase in } \\
\text { production costs } \\
\text { for supporting } \\
\text { sub-stock } \\
\text { warehouse } \\
\text { stock costs }\end{array}$ & 5 & 4 & 20 & $C$ & 4 \\
\hline A29 & $\begin{array}{l}\text { An error } \\
\text { occurred when } \\
\text { the finished } \\
\text { product was } \\
\text { stacked }\end{array}$ & 2 & 3 & 6 & $M$ & 33 \\
\hline A30 & $\begin{array}{l}\text { Nonstandard of } \\
\text { material } \\
\text { distribution } \\
\text { facilities }\end{array}$ & 4 & 5 & 20 & $C$ & 5 \\
\hline $\mathrm{A} 31$ & $\begin{array}{l}\text { The } \\
\text { unavailability of }\end{array}$ & 2 & 3 & 6 & $M$ & 34 \\
\hline
\end{tabular}

\begin{tabular}{|c|c|c|c|c|c|c|}
\hline Code & Risk Identified & LO & LS & RPI & LR & $\mathbf{R P}$ \\
\hline & $\begin{array}{l}\text { transportation } \\
\text { for shipping }\end{array}$ & & & & & \\
\hline A32 & $\begin{array}{l}\text { Product delays } \\
\text { that reach } \\
\text { consumers }\end{array}$ & 3 & 3 & 9 & $M J$ & 28 \\
\hline A33 & $\begin{array}{l}\text { The uncertainty } \\
\text { of delivery date } \\
\text { of transported } \\
\text { forwarders }\end{array}$ & 3 & 3 & 9 & $M J$ & 29 \\
\hline A34 & $\begin{array}{l}\text { Material late } \\
\text { due to payment } \\
\text { problems to } \\
\text { suppliers }\end{array}$ & 2 & 1 & 2 & $M N$ & 37 \\
\hline A35 & $\begin{array}{l}\text { Defective } \\
\text { products during } \\
\text { production }\end{array}$ & 4 & 4 & 16 & $C$ & 8 \\
\hline A36 & $\begin{array}{l}\text { Product returns } \\
\text { from consumers } \\
\text { (returned well) }\end{array}$ & 3 & 4 & 12 & $M J$ & 15 \\
\hline A37 & $\begin{array}{l}\text { Damage when } \\
\text { shipping and } \\
\text { decreasing } \\
\text { finished } \\
\text { products } \\
\text { (precast) }\end{array}$ & 2 & 3 & 6 & $M$ & 35 \\
\hline
\end{tabular}

Note: LO: Level of Occurrence, LS: Level of Severity, RPI: Risk Priority Index, LR: Level of Risk (i.e. MN: Minor, M: Moderate, MJ: Major, C: Critical), RP: Risk Priority

\subsection{Risk mapping, response, and mitigation strategies}

Table 2 describes the level of risks classified as minor, moderate, major, and critical. These risks will be responded by the companies based on their risk levels, as follows:

1. Retain (accept). The response of minor risks by accepting risks and maintaining the level of risk as it is.

2. Mitigate (reduce). The response of moderate risks by lowering the level of occurrence and/or level of severity, so that the threat of the risks to the company's operations is no longer significant.

3. Transfer (share). The major risks are transferred to other parties so that the risk arising is no longer solely the responsibility of the company.

4. Avoid (prevent at source). The critical risks are not acceptable and will be avoided as much as possible, or the company takes extraordinary actions to minimize the risk to the sources of the risks.

Table 3 shows the distribution of 37 risks of supply chain activities of WKB. It can be seen that the risk levels are dominated by major risks (54\%), followed by critical risks $(24 \%)$, moderate risks (19\%), and minor risks (3\%). Based on SCOR model, the highest number of risks is in the 'Make' (35\%), followed by Plan (22\%), Source $(22 \%)$, Deliver (14\%), and Return (8\%). Critical risks are found mostly in the 'Make' $11 \%$, and Plan (5\%). 
Table 3. Risk Distribution of the SCOR model and responses

\begin{tabular}{|l|c|c|c|c|c|}
\hline \multicolumn{1}{|c|}{ SCOR } & Minor & Moderate & Major & Critical & Total \\
\hline Plan & - & $1(3 \%)$ & $5(14 \%)$ & $2(5 \%)$ & $\begin{array}{c}8 \\
(22 \%)\end{array}$ \\
\hline Source & - & $1(3 \%)$ & $6(16 \%)$ & $1(3 \%)$ & $\begin{array}{c}8 \\
(22 \%)\end{array}$ \\
\hline Make & - & $3(8 \%)$ & $6(16 \%)$ & $4(11 \%)$ & $\begin{array}{c}13 \\
(35 \%)\end{array}$ \\
\hline Deliver & $1(3 \%)$ & $1(3 \%)$ & $2(5 \%)$ & $1(3 \%)$ & $\begin{array}{c}5 \\
(14 \%)\end{array}$ \\
\hline Return & - & $1(3 \%)$ & $1(3 \%)$ & $1(3 \%)$ & $3(8 \%)$ \\
\hline TOTAL & $1(3 \%)$ & $7(19 \%)$ & $20(54 \%)$ & $9(24 \%)$ & $\begin{array}{c}37 \\
(100 \%)\end{array}$ \\
\hline Response & $\begin{array}{c}\text { Retain } \\
/ \text { accept }\end{array}$ & $\begin{array}{c}\text { Mitigate / } \\
\text { reduce }\end{array}$ & $\begin{array}{c}\text { Transfer/ } \\
\text { share }\end{array}$ & $\begin{array}{c}\text { Avoid/ } \\
\text { prevent } \\
\text { at source }\end{array}$ \\
\hline
\end{tabular}

The identification process of risk mitigation strategies was carried out based on discussions and in-depth interviews, and verification of these mitigation actions was carried out in the FGD as part of the communication process with all risk owners. Table 4 shows the nine critical risks in order and relevant mitigation strategies for each critical risk.

Table 4. Mitigation strategies of critical risks

\begin{tabular}{|c|c|c|c|}
\hline Risks & $\begin{array}{c}\text { Risk } \\
\text { Explanation }\end{array}$ & $\begin{array}{c}\text { Mitigation } \\
\text { Strategy }\end{array}$ & SCOR \\
\hline (1) & (2) & (3) & (4) \\
\hline $\begin{array}{l}\text { (A1) } \\
\text { Sales forecast } \\
\text { not accurate }\end{array}$ & $\begin{array}{l}\text { Risks related } \\
\text { to sales } \\
\text { forecasts are } \\
\text { inaccurate }\end{array}$ & $\begin{array}{l}\text { Supply chain } \\
\text { companies and } \\
\text { partners work } \\
\text { together to develop } \\
\text { forecasting on } \\
\text { product demand } \\
\text { from consumers, } \\
\text { supported by the } \\
\text { latest methods and } \\
\text { technologies to } \\
\text { obtain more } \\
\text { optimal forecasting } \\
\text { results. }\end{array}$ & Plan \\
\hline $\begin{array}{l}\text { (A14) } \\
\text { The reduced } \\
\text { production } \\
\text { capacity of } \\
\text { several } \\
\text { vendors, } \\
\text { especially in } \\
\text { split material }\end{array}$ & $\begin{array}{l}\text { Risks that } \\
\text { occur relate to } \\
\text { the absence or } \\
\text { unavailability } \\
\text { of raw } \\
\text { materials to } \\
\text { fulfil orders, } \\
\text { forecast, stock } \\
\text { replenishment, } \\
\text { so that } \\
\text { production is } \\
\text { stopped, } \\
\text { disrupted, does } \\
\text { not finish } \\
\text { supplying } \\
\text { products }\end{array}$ & $\begin{array}{l}\text { Long-term intimacy } \\
\text { with suppliers } \\
\text { through a contract } \\
\text { agreement to ensure } \\
\text { uninterrupted } \\
\text { continuity of supply } \\
\text { of raw materials at } \\
\text { prices that are not } \\
\text { too volatile and of } \\
\text { good quality }\end{array}$ & Source \\
\hline $\begin{array}{l}\text { (A17) } \\
\text { Changes in } \\
\text { sudden } \\
\text { production } \\
\text { plans }\end{array}$ & $\begin{array}{l}\text { Risks related } \\
\text { to events are } \\
\text { related to } \\
\text { changes in } \\
\text { unplanned } \\
\text { production } \\
\text { plans due to } \\
\text { various causes } \\
\text { and factors, } \\
\text { which are } \\
\text { sudden. }\end{array}$ & $\begin{array}{l}\text { Optimizing inter- } \\
\text { part coordination } \\
\text { and communication } \\
\text { through the multi- } \\
\text { discipline team for } \\
\text { increasing } \\
\text { productivity, } \\
\text { reducing waste, } \\
\text { increasing process } \\
\text { efficiency, cross- } \\
\text { section problem } \\
\text { solving / unit, and } \\
\text { etc. }\end{array}$ & Make \\
\hline
\end{tabular}

\begin{tabular}{|c|c|c|c|}
\hline Risks & $\begin{array}{c}\text { Risk } \\
\text { Explanation }\end{array}$ & $\begin{array}{c}\text { Mitigation } \\
\text { Strategy }\end{array}$ & SCOR \\
\hline (1) & (2) & (3) & (4) \\
\hline $\begin{array}{l}\text { (A28) } \\
\text { Increase in } \\
\text { production } \\
\text { costs for } \\
\text { supporting } \\
\text { sub-stock } \\
\text { warehouse } \\
\text { stock costs }\end{array}$ & $\begin{array}{l}\text { Risks related } \\
\text { to the } \\
\text { availability of } \\
\text { products that } \\
\text { are ordered } \\
\text { outside of } \\
\text { production } \\
\text { capacity so } \\
\text { that they need } \\
\text { additional to } \\
\text { avoid delays in } \\
\text { the production } \\
\text { process. }\end{array}$ & $\begin{array}{l}\text { Borrowing printing } \\
\text { equipment and } \\
\text { spending budget for } \\
\text { purchasing printing } \\
\text { equipment }\end{array}$ & Make \\
\hline $\begin{array}{l}\text { (A30) } \\
\text { Nonstandard } \\
\text { material } \\
\text { distribution } \\
\text { facilities }\end{array}$ & $\begin{array}{l}\text { This risk is } \\
\text { related to the } \\
\text { unavailability } \\
\text { of } \\
\text { transportation } \\
\text { for delivery to } \\
\text { customers } \\
\text { when needed } \\
\text { or the delivery } \\
\text { deadline }\end{array}$ & $\begin{array}{l}\text { Looking for } \\
\text { alternative transport } \\
\text { that has good } \\
\text { flexibility }\end{array}$ & Deliver \\
\hline $\begin{array}{l}\text { (A3) } \\
\text { Weak } \\
\text { planning and } \\
\text { preparation } \\
\text { carried out } \\
\text { prior to } \\
\text { production }\end{array}$ & $\begin{array}{l}\text { Risks related } \\
\text { to production } \\
\text { planning } \\
\text { mismatches } \\
\text { with requests } \\
\text { or orders, both } \\
\text { related to } \\
\text { priorities, } \\
\text { quantities, } \\
\text { deadlines and } \\
\text { so on. }\end{array}$ & $\begin{array}{l}\text { Coordination with } \\
\text { the production } \\
\text { section and } \\
\text { equipment related } \\
\text { to the production } \\
\text { implementation } \\
\text { process and } \\
\text { monitoring } \\
\text { inventory levels } \\
\text { between realization } \\
\text { and plans }\end{array}$ & Plan \\
\hline $\begin{array}{l}\text { (A24) } \\
\text { Less skilled } \\
\text { workforce }\end{array}$ & $\begin{array}{l}\text { Risks related } \\
\text { to the lack of } \\
\text { labour needed } \\
\text { for the } \\
\text { production } \\
\text { process, both } \\
\text { anticipated and } \\
\text { not }\end{array}$ & $\begin{array}{l}\text { Matrix skill } \\
\text { development for } \\
\text { workers to improve } \\
\text { workers' skills to be } \\
\text { multi-workers and } \\
\text { reward motivation } \\
\text { for workers to have } \\
\text { more than } 1 \text { skill. }\end{array}$ & Make \\
\hline $\begin{array}{l}\text { (A35) } \\
\text { Defective } \\
\text { products } \\
\text { during } \\
\text { production }\end{array}$ & $\begin{array}{l}\text { Risks related } \\
\text { to the } \\
\text { occurrence of } \\
\text { defective, } \\
\text { rejected, } \\
\text { contaminated, } \\
\text { or reworked } \\
\text { products } \\
\text { before the } \\
\text { product reach } \\
\text { the consumer }\end{array}$ & $\begin{array}{l}\text { Maintaining the } \\
\text { quality of the } \\
\text { product according } \\
\text { to the quality } \\
\text { objectives set by } \\
\text { the company, } \\
\text { namely in one year } \\
\text { the defect is not } \\
\text { more than } 1.2 \% \text { and } \\
\text { fails not more than } \\
0.4 \% \text {. }\end{array}$ & Return \\
\hline $\begin{array}{l}\text { (A27) } \\
\text { The period of } \\
\text { land lease } \\
\text { permits } \\
\text { expired }\end{array}$ & $\begin{array}{l}\text { This risk is } \\
\text { related to the } \\
\text { occurrence of a } \\
\text { forced } \\
\text { shutdown plant } \\
\text { that stops all } \\
\text { operations in } \\
\text { the supply } \\
\text { chain due to } \\
\text { various } \\
\text { reasons }\end{array}$ & $\begin{array}{l}\text { Complete the } \\
\text { required documents } \\
\text { and monitor the } \\
\text { continued } \\
\text { maintenance of } \\
\text { legal permits }\end{array}$ & Make \\
\hline
\end{tabular}

The first rank of the nine critical risks is 'Sales forecast not accurate', which is in the 'Plan' dimension. The relevant strategy, i.e. WKB to work together with partners to develop forecasting on product demand from consumers, supported by the latest methods and technologies to obtain more optimal forecasting results. 
The other risk in 'Plan' dimension (rank 6) is 'Weak planning and preparation carried out prior to production'. The proposed mitigation strategy for this risk is to increase coordination with the production section and equipment related to the production implementation process and monitoring inventory levels between realization and plans.

The second rank of the risk is 'The reduced production capacity of several vendors', which is in the 'Source' dimension. The mitigation strategy includes building a long-term relationship with suppliers through a contract agreement to guarantee the continuity of supply of raw materials at stable prices and of good quality.

Of the nine critical risks, the risks are dominated by 'Make' dimension (35\%), i.e. changes in sudden production plans, increase in production costs for supporting sub-stock warehouse stock costs, less skilled workforce, nonstandard of material distribution facilities, and the period of land lease permits expired. For these risks, the relevant mitigation strategies include, e.g. optimizing coordination and communication through the multi-discipline team to increase productivity, spending budget for purchasing relevant equipment, developing skills and giving rewards to motivate workers, and providing relevant legal documents.

The other two risks are related to "Non-standard material distribution facilities', and 'Defective products during production', which are in 'Deliver' and 'Return' dimensions, respectively. The relevant mitigation strategies include, i.e. looking for alternative transport that has good flexibility, and maintaining the quality of the product according to the quality objectives set by the company.

\section{Discussion}

The results show that the majority of the risks identified are related to 'Make' dimension (35\%). In addition, 4 out of 9 critical risks are also identified in this dimension, which consists of two sub-processes, i.e. the process of production and handling of the finished products. As activities within these subprocesses are parts of the internal business process, these risks are relatively controllable to top management of WKB.

To enhance the process of production of the precast concrete, innovation can be made from the traditional approach of production-scheduling to the integration of the whole process of the mould manufacturing, storing, and transporting [32]. This approach may eventually improve the feasibility of the production process, promote on-time delivery, and saving costs up to $35 \%$.

Risks identified in 'Plan' dimension account for $22 \%$ of the total risks. In fact, the first rank of the 9 critical risks, i.e. 'Sales forecast not accurate' is in the 'Plan' dimension. It consists of the demand for concrete products and production planning. It is understood that the demand for concrete products depends on the external market. Although it can be estimated, the risks related to this demand is not fully controllable to the management of WKB. One of the ideas of remedies for this problem is by integrating commercial information between trading parties' back-end systems through e-trading system called the electronic exchange of commercial information (eCIX) [33].

On the other hand, the production planning is dependent on the market demand. The capacity of the resources for production, e.g. materials, tools, human resources, etc, will be adjusted following the estimated size of the demand. While these type of risks in the production planning will be likely controllable to the management, yet a comprehensive planning is a must to avoid problems. In fact, there are many common supply chain problems occurring on construction sites can be traced back from the lack of planning at the company/preconstruction level [34].

'Sources' dimension, which consists of procurement of materials, and raw material testing, acceptance, and inspection, accounts for $22 \%$ out of 37 risks. While risks of material testing, acceptance, and inspection are mostly within the control of top management, the risks of material procurement are more likely related to external parties, which might become significant challenges in terms of controlling the risks. Activities related to material procurement include price negotiation, supplier selection, receive of raw material delivery, evaluation of supplier assessment.

Related to these problems, an optimization model has been proposed to enhance supply network performance with smaller investment, including the formulation of decision parameters for supplier selection and the implementation of multi-suppler configurations [35]. This model is expected to be able to minimize the risks of disruption, particularly for critical purchasing elements, which may cause major process disruptions to the manufacturing process.

As much as $14 \%$ of the total risks are identified in the 'Deliver' dimension, which consists of activities of delivery and after sales service, and bill handling. Activities in delivery include the selection of means of transportation, information on field conditions, and delivery schedule information. Several models have been proposed in terms of improving deliveries of precast concrete, e.g. optimizing batch deliveries for precast concrete using just-in-time (JIT) management approach [36], modelling the manufacture, transportation and onsite assembly of the precast concrete as a whole process from the point of view of a single machine batchscheduling model to improve the efficiency of the precast concrete production [37].

The 'Return' dimension has the lowest risk of $8 \%$. Activities related to this include handling of rejected materials by customers or failed/defective products at the time of production/installation. In practice, it is considerably rare to return products of precast concrete to the suppliers, which explains the lowest number of risks for this dimension. However, to minimise the number of rejected products due to defects, a non-contact dimensional quality assurance (DQA) method has been developed to evaluate the key quality measures of precast concrete elements in full-size utilising laser scanning and Building Information Modeling (BIM) as the tools [38]. 


\section{Conclusion}

This research has successfully identified a total of 37 risks of the precast concrete supply chain of WKB as a case study and has recommended appropriate responses and mitigation strategies. Based on the five dimensions of SCOR model, the highest number of risks is identified in the 'Make' (35\%), followed by 'Plan' (22\%), 'Source' (22\%), 'Deliver' (14\%), and 'Return' (8\%). The risk levels are dominated by major risks $(54 \%)$, followed by critical risks $(24 \%)$, moderate risks $(19 \%)$, and minor risks $(3 \%)$.

A total of 9 critical risks were identified along the supply chain, mostly in the 'Make' $11 \%$, and Plan (5\%), with appropriate risk response of 'to be avoided/ prevented from the source'. These critical risks include i.e. sales forecast and planning for production (Plan); production capacity of natural material vendors (Source); sudden change of production, shortage of skilled workers, additional cost for land stockyard rental, and renewal for industrial land lease license (Make); risk of non-standard transportation (Deliver); defective and failed products (Return).

This research was done using a case study of WKB, a government-owned precast concrete company. To produce a more accurate analysis in risk management precast supply chain, more in-depth approach and more respondents are needed, such as contractors, consultants, designers, project owners, including the need for academics or personnel experts. Nevertheless, this research provides a valuable understanding of the risks of the precast concrete supply chain and the mitigation strategies. Future research could explore more on risks of the precast concrete supply chain in various case studies, particularly related to activities in the project sites.

\section{References}

1. S. Gold, S. Seuring, P. Beske, Sustainable supply chain management and inter-organizational resources: a literature review, Corp. Soc. Resp. Env. Ma. 17 (2010) 230-245.

2. P. E. Eriksson, Improving construction supply chain collaboration and performance: a lean construction pilot project, Supply Chain Manag., 15 (2010) 394403.

3. M. Cao, Q. Zhang, Supply chain collaboration: Impact on collaborative advantage and firm performance, J. Oper. Manag., 29 (2011) 163-180.

4. C. Dossche, V. Boel, W. D. Corte, P.V.D. Heede, N.D. Belie, A plant based LCA of high-strength prestressed concrete elements and the assessment of a practical ecological variant, Cement Concrete Comp., 73 (2016) 192-202.

5. Z. Wang, H. Hu, Improved precast productionscheduling model considering the whole supply chain, J. Comput. Civil Eng., 31 (2017) 04017013.

6. L. Kong, H. Li, H. Luo, L. Ding, X. Zhang, Sustainable performance of just-in-time (JIT) management in time-dependent batch delivery scheduling of precast construction, J. Clean. Prod., 193 (2018) 684-701.

7. W.M.S.W. Omar, J.-H. Doh, K. Panuwatwanich, D. Miller, Assessment of the embodied carbon in precast concrete wall panels using a hybrid life cycle assessment approach in Malaysia, Sustain. Cities Soc., 10 (2014) 101-111.

8. M. Loosemore, J. Raftery, C. Reilly, D. Higgon, Risk management in projects, (Routledge, 2012).

9. M.M.d. Carvalho, R. Rabechini Junior, Impact of risk management on project performance: the importance of soft skills, Int. J. Prod. Res., 53 (2015) 321-340.

10. J.P. Paquin, C. Gauthier, P.P. Morin, The downside risk of project portfolios: The impact of capital investment projects and the value of project efficiency and project risk management programmes, Int. J. Proj. Man., 34 (2016) 1460-1470.

11. H.A. Hornstein, The integration of project management and organizational change management is now a necessity, Int. J. Proj. Man., 33 (2015) 291-298.

12. M. Arashpour, Y. Bai, G. Aranda-mena, A. BabHadiashar, R. Hosseini, P. Kalutara, Optimizing decisions in advanced manufacturing of prefabricated products: Theorizing supply chain configurations in off-site construction, Automat. Constr., 84 (2017) 146-153.

13. M. Arashpour, B. Abbasi, M. Arashpour, M.R. Hosseini, R. Yang, Integrated management of onsite, coordination and off-site uncertainty: theorizing risk analysis within a hybrid project setting, Int. J. Proj. Man., 35 (2017) 647-655.

14. C.Z. Li, J. Hong, F. Xue, G.Q. Shen, X. Xu, M.K. Mok, Schedule risks in prefabrication housing production in Hong Kong: a social network analysis, J. Clean. Prod., 134 (2016) 482-494.

15. S.H. Huan, S.K. Sheoran, G. Wang, A review and analysis of supply chain operations reference (SCOR) model, Supply Chain Manag., 9 (2004) 2329.

16. M.A. Wibowo, M.N. Sholeh, The analysis of supply chain performance measurement at construction project, Procedia Engineering, 125 (2015) 25-31.

17. J.C. Cheng, K.H. Law, H. Bjornsson, A. Jones, R. Sriram, A service oriented framework for construction supply chain integration, Automat. Constr., 19 (2010) 245-260.

18. J.U.D. Hatmoko, S. Scott, Simulating the impact of supply chain management practice on the performance of medium-sized building projects, Constr. Man. Econ., 28 (2010) 35-49.

19. C. Wu, D. Barnes, An integrated model for green partner selection and supply chain construction, J. Clean. Prod., 112 (2016) 2114-2132.

20. J.U.D. Hatmoko, S. Scott, Simulating the impact of supply chain management practice on construction project performance, Assoc. Res. Constr. Man., ARCOM, (2006) 447-457.

21. S.W. Mudjanarko, M.I. Setiawan, C. Hasyim, Concrete Technology to Support Sustainable Tourism Infrastructure, ADRI Int. J. Civ. Eng., 1 (2017) 7-9. 
22. J.-L. Gálvez-Martos, D. Styles, H. Schoenberger, B. Zeschmar-Lahl, Construction and demolition waste best management practice in Europe, Res. Conserv. Recy., 136 (2018) 166-178.

23. M.N. Sholeh, S. Fauziyah, Current state mapping of the supply chain in engineering procurement construction (EPC) project: a case study, (MATEC Web of Conferences, EDP Sciences, 2018, pp. 06015).

24. J. Hong, G.Q. Shen, C. Mao, Z. Li, K. Li, Life-cycle energy analysis of prefabricated building components: an input-output-based hybrid model, J. Clean. Prod., 112 (2016) 2198-2207.

25. W. Ho, T. Zheng, H. Yildiz, S. Talluri, Supply chain risk management: a literature review, Int. J. Prod. Res., 53 (2015) 5031-5069.

26. I. Heckmann, T. Comes, S. Nickel, A critical review on supply chain risk-Definition, measure and modeling, Omega, 52 (2015) 119-132.

27. D. Aloini, R. Dulmin, V. Mininno, S. Ponticelli, Supply chain management: a review of implementation risks in the construction industry, Bus. Proc. Man. J., 18 (2012) 735-761.

28. T.F. dos Santos, M.S.A. Leite, Performance measurement system based on supply chain operations reference model: review and proposal, (2018).

29. D. Jothimani, S. Sarmah, Supply chain performance measurement for third party logistics, Bench. Int. J., 21 (2014) 944-963.

30. M.A. Wibowo, M.N. Sholeh, H.S. Adji, Supply chain management strategy for recycled materials to support sustainable construction, Procedia engineering, 171 (2017) 185-190.

31. M.A. Wibowo, M.N. Sholeh, Application of supply chain performance measurement in scor model at building project, IPTEK Journal of Proceedings Series, 3 (2017) 60-64.

32. Z. Wang, H. Hao, G. Jie, Framework for modeling operational uncertainty to optimize offsite production scheduling of precast components, Automat. Constr., 86 (2018) 69-80.

33. M. Pala, F. Edum-Fotwe, K. Ruikar, C. Peters, N. Doughty, Implementing commercial information exchange: a construction supply chain case study, Constr. Man. Econ., 34 (2016) 898-918.

34. M. Thunberg, A. Fredriksson, Bringing planning back into the picture-How can supply chain planning aid in dealing with supply chain-related problems in construction?, Constr. Man. Econ., (2018) 1-18.

35. M. Arashpour, Y. Bai, G. Arandamena, A. BabHadiashar, R. Hosseini, P. Kalutara, Optimizing decisions in advanced manufacturing of prefabricated products: Theorizing supply chain configurations in off-site construction, Auto. Cons., 84 (2017) 146-153

36. L. Kong, H. Li, H. Luo, L. Ding, X. Zhang, Sustainable performance of just-in-time (JIT) management in time-dependent batch delivery scheduling of precast construction, J. Clean. Prod., 193 (2018) 684-701.

37. L. Kong, H. Li, H. Luo, L. Ding, X. Luo, M. Skitmore, Optimal single-machine batch scheduling for the manufacture, transportation and JIT assembly of precast construction with changeover costs within due dates. Automat. Constr., 81 (2017) 34-43.

38. M.K. Kim, Q. Wang, J.W. Park, J.C.P. Cheng, H. Sohn, C.C. Chang. Automated dimensional quality assurance of full-scale precast concrete elements using laser scanning and BIM. Automat. Constr., 72 (2016) 102-114. 